\title{
Hemostasis Technique Using an Adjustable Nylon Tie in Dog with Splenic Hematoma and Lymphoid Hyperplasia
}

\author{
Ivan Felismino Charas dos Santos ${ }^{1,2}$, Maira Duarte Del Poente ${ }^{3}$, Giovanna Cristina Brombini², \\ Mayara Viana Freire Gomes², Bruna Martins da Silva², Sheila Canevese Rahal², \\ Filipe Carrari Isaac Tannus ${ }^{2}$, Frederico Matheus Ducatti de Góis ${ }^{2}$ \& Maria Gabriela Picelli de Azevedo ${ }^{4}$
}

\begin{abstract}
Background: Splenic hematoma is an encapsulated blood accumulation, which is macroscopically indistinguishable from malignant spleen. The treatment of choice and final diagnosis were by splenectomy and exploratory laparotomy followed by biopsy and histopathological examination, respectively. Nylon tie bands are devices made of polyamide 6.6, same material of surgical nylon wires, and has been used in different surgical procedures in animals. The present report case aimed to describe the use of nylon tie bands polyamide 6.6 in a 2.3-year-old Golden retriever dog diagnosed with splenic hematoma and lymphoid hyperplasia; and the clinical presentation, diagnostic evaluation, histological diagnosis of splenic hematoma and lymphoid hyperplasia.

Case: A 2.3-year-old intact male Golden retriever dog was presented with history of anorexia, apathy, regurgitation and weight loss. During the physical examination was identified a mass in the left side of abdomen. The complete blood count (CBC), serum biochemistry, urinalysis, and thoracic radiographs were no alteration. Abdominal ultrasound revealed splenomegaly and heterogeneous hypoechoic structure. Splenectomy using an adjustable nylon ties polyamide 6.6 for hemostasis technique was performed during an exploratory laparotomy. The spleen presented hematoma and lymphoid hyperplasia at the histopathological examination, as well as the presence of siderocalcinotic plate in the trabecular spleen. The dog presented with no regurgitation, apathy or anorexia after 10 days of surgery. CBC, serum biochemistry analysis, thoracic radiographs and abdominal ultrasound revealed no abnormalities. Video laparoscopy did not showed any sign of adherence on the local where used the nylon tie bands. One year and three months after the surgery, the owner was contacted by telephone, since he had changed to other city, and he reported that the dog was healthy without any clinical signs. Discussion: The present case report describes the using of nylon tie polyamide 6.6 bands in a 2.3-year-old Golden retriever dog diagnosed with splenic hematoma and lymphoid hyperplasia. According to the author's knowledge, the present case is the first report regarding to using nylon tie bands in splenectomy, and clinical characteristics of hematoma and lymphoid hyperplasia in young dog. The adjustable nylon tie bands allowed a secure and faster ligature when compared with traditional nylon surgical suture wires in different surgical procedures in animals and humans patients, and was considered well tolerated and non-toxic. Reports concerning to complications to the use of nylon tie in veterinary surgery were present in the literature. Otherwise, these complications were related to surgical technique failure and inadequate aseptic technique; inadequate use of nylon tie bands before assigning it as a hemostatic material. Partial splenectomy is recommended for treatment of splenic hematoma and lymphoid hyperplasia in dogs whenever possible; however, the macroscopic findings concerning splenic disorders are not enough to set the distinction between benign and malignant disorders. Clinical sign associated with splenic disorders in the present case was abdominal distension due to hematoma and nodular lymphoid hyperplasia. An adjustable nylon tie polyamide 6.6 band can be used to clamp the spleen vessels, gastroepiploic artery, gastric artery and omento veins.
\end{abstract}

Keywords: polyamide bands, lymphoid follicle, spleen, splenectomy vessels ligature.

${ }^{1}$ Pós-Doutorando (Bolsista Fapesp). ${ }^{2}$ Departamento de Cirurgia e Anestesiologia Veterinária (DCAV), Faculdade de Medicina Veterinária e Zootecnia (FMVZ), Universidade Estadual Paulista (UNESP), Botucatu, SP, Brazil. ${ }^{3}$ M.V. Autônoma, São Paulo, SP. ${ }^{4}$ Departamento de Clínica Veterinária, FMVZ - UNESP Botucatu. CORRESPONDENCE: I.F.C. Santos [ivansantos7@ hotmail.com - Tel.: +55 (14) 3880-2022]. Faculdade de Medicina Veterinária e Zootecnia - UNESP. Distrito de Rubião Junior, s/n. CEP 18618-681 Botucatu, SP, Brazil. 


\section{INTRODUCTION}

Splenic hematoma is an encapsulated blood accumulation, which is macroscopically indistinguishable from malignant spleen disorders such as hemangiosarcoma [1]. The exploratory laparotomy followed by biopsy and histopathological examination are used for final diagnosis $[9,13]$. The lymphosarcoma, hemangioma, hemangiosarcoma, fibrossarcoma, splenic abscess and splenic torsion were used as differential diagnoses; and splenectomy is the treatment of choice [9].

Nylon tie bands devices are devices which are produced with the same material of surgical nylon wires - polyamide 6.6 [28]. The device is well tolerated and non-toxic $[6,10]$. It has been used in different surgical procedures in animals $[4,6,23,28,29]$ and humans patients [7,27]. However, there is no report in the literature concerning using nylon tie bands in splenectomy, and reports of splenic hematoma and lymphoid hyperplasia in young dogs are rare in the literature, and have relevance to the clinical routine as to the method of diagnosis and surgical approach. The authors aim to describe the use of an adjustable nylon tie polyamide 6.6 band in a 2.3-year-old Golden retriever dog diagnosed with splenic hematoma and lymphoid hyperplasia. The clinical presentation, diagnostic evaluation, histological diagnosis of splenic hematoma and lymphoid hyperplasia is also herein described.

\section{CASE}

A 2.3-year-old intact male Golden retriever dog weighing $28 \mathrm{~kg}$ was presented to the private practice in São Paulo City, Brazil, with anorexia, apathy, regurgitation and weight loss, with 10 days' duration. Water intake was not unsettled. Urine and feces were normal. Vaccination and deworming were up to date. On physical examination there was identified a mass in the left hypochondriac region and in the left lombar region. The abdomen was distended; however, there was no sign of pain during abdominal palpation. The remainder of the physical examination was within normal.

Complete blood count (CBC), serum biochemical (alanine aminotransferase - ALT, urea and creatinine) and urinalysis were within normal limits. Ventrodorsal, right and left lateral thoracic radiographs revealed no abnormalities. Abdominal ultrasound examination revealed splenomegaly and a heterogeneous hypoechoic structure with approximately $19.05 \mathrm{~cm} \mathrm{x}$ $17.28 \mathrm{~cm}$, suggesting a splenic tumour.
According to physical and ultrasounds examinations results it was decided to perform an exploratory laparotomy and splenectomy. The owner allowed the surgery by signed of commitment term. The dog was premedicated with $4.4 \mathrm{mg} \mathrm{kg}^{-1}$ subcutaneous (SC) of carprofen (Rimadyl $\left.{ }^{\circledR}\right)^{1}, 0.3 \mathrm{mg} \mathrm{kg}^{-1}$ (SC) of morphine $\left(\text { Dimorf }^{\circledR}\right)^{2}$ and $0.05 \mathrm{mg} \mathrm{kg}^{-1}$ intramuscularly of acepromazine $\left(\text { Acepran }^{\circledR}\right)^{3}$. Anaesthesia was induced with $2.5 \mathrm{mg} \mathrm{kg}^{-1}$ intravenous of propofol (Diprivan $\left.{ }^{\circledR}\right)^{4}$ and maintained with isoflurane $\left(\text { Forane }^{\circledR}\right)^{5}$ in $\mathrm{O}_{2}$ via a $8 \mathrm{~mm}$ cuffed endotracheal tube. Crystalloid fluids were administered intravenous at $5 \mathrm{~mL} \mathrm{~kg}^{-1} \mathrm{~h}^{-1}$. Exploratory laparotomy was performed through ventral midline incision and it revealed the presence of a mass in the left splenic lobe and a splenic body with $12 \mathrm{~cm}$ diameter, irregular surface, dark red color and large vessels (Figure 1A, 1B, 1C). There was no visible evidence of alterations in other organs. A splenectomy was performed using an adjustable nylon tie polyamide 6.6 bands (100 mm x $2.50 \mathrm{~mm}$ ) (Abraçadeira de nylon $\left.{ }^{\circledR}\right)^{6}$ to clamp following branch of vessels: splenic artery and splenic vein, gastroepiploic artery, gastric artery; and omento vessels (Figure 1D, 1E). The muscular layer was closed with Sultan sutures using 2-0 nylon (Nylon 2-0 Shalon $\left.{ }^{\circledR}\right)^{7}$ and subcutaneous layer was closed with simple continuous suture with 2-0 polyglactin (Vicryl Rapide - poliglactina $\left.910^{\circledR}\right)^{8}$. The skin edges were opposed with interrupted simple sutures using 3-0 nylon ( Nylon 3-0 Shalon $\left.{ }^{\circledR}\right)^{7}$.

The nylon tie was sterilized in autoclave, $121^{\circ} \mathrm{C}$ for $30 \mathrm{~min}$ [25] previously the surgical procedure. Nylon tie excess was cut off. The dog recovered uneventfully from surgery. It was prescribed $15 \mathrm{mg} \mathrm{kg}^{-1}$ TID orally for 4 days of dipyrone (Dipirona Sódica $\left.{ }^{\circledR}\right)^{9}$ and $0.1 \mathrm{mg} \mathrm{kg}^{-1}$ SID orally for 5 days of meloxican $\left(\text { Maxicam }^{\circledR}\right)^{10}$ and $15 \mathrm{mg} \mathrm{kg}^{-1}$ BID orally for 10 days of cephalexin $\left(\operatorname{Keforal}^{\circledR}\right)^{11}$.

The histopathological examination carried out to the spleen and to the mass revealed a nodular outlined lesion, increased spleen parenchyma, hemorrhage, hyperplasic lymphoid follicles, lymphocytes and lymphoplasmatic cells (Figure 2A, 2B). On the other hand, thickness of connective tissue trabeculae and accumulation of hemosiderin, hematoidina and refractive calcareous were observed. There was no evidence of malignant lesion. The diagnosis evidenced splenic hematoma, lymphoid hyperplasia and siderocalcinotic plate in spleen trabeculae. 
I.F.C. Santos, M.D. Del Poente, G.C. Brombini, et al. 2017. Hemostasis Technique Using an Adjustable Nylon Tie in Dog with Splenic Hematoma and Lymphoid Hyperplasia.

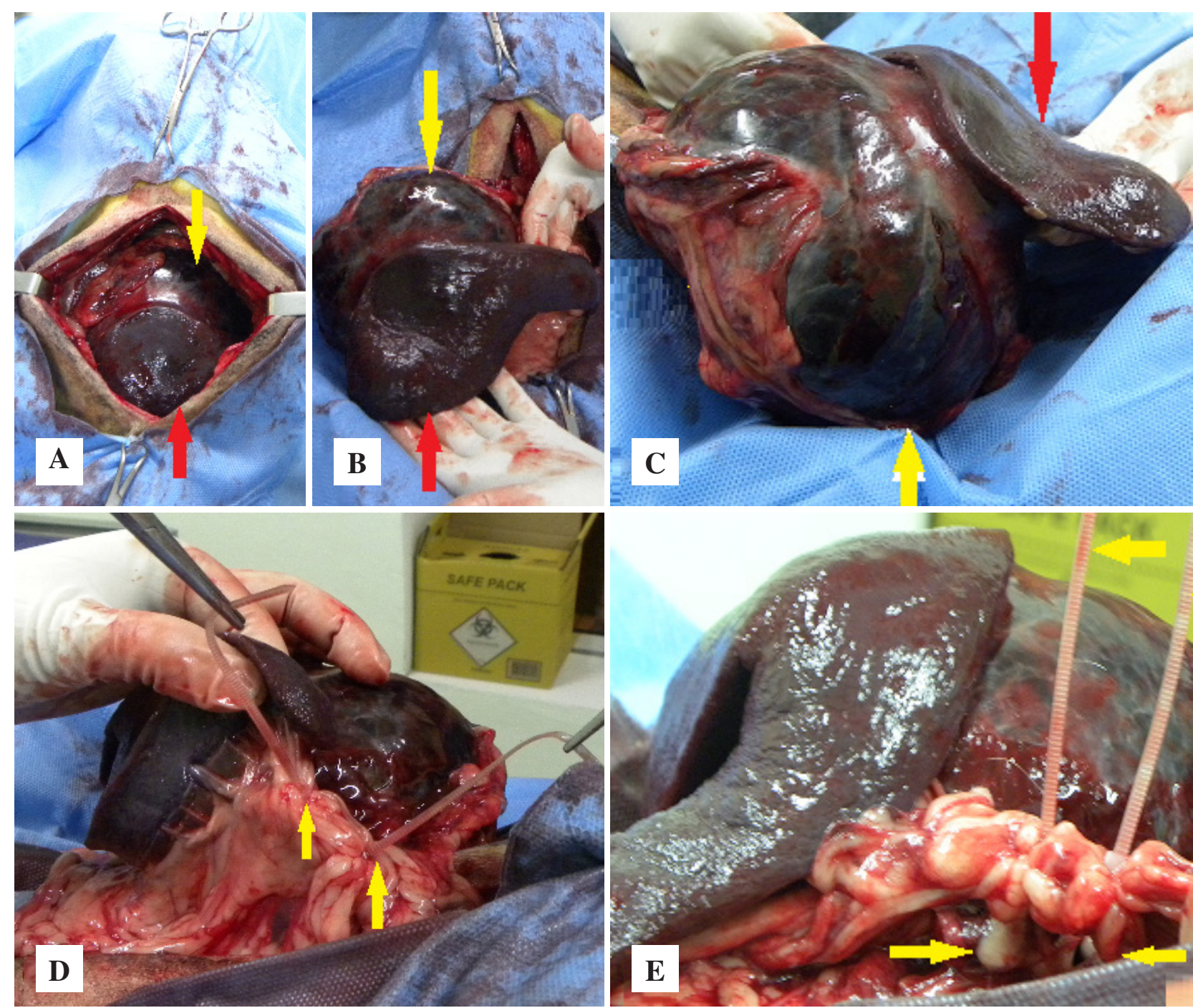

Figure 1. A,B,C - Photography showing a mass with $12 \mathrm{~cm}$ diameter with wine color (yellow arrow) on left splenic lobe and body (red arrow) and large vessels of a 2.3-year-old Golden retriever, diagnosed with splenic hematoma associated with lymphoid hyperplasia. D,E- Clamping of gastroepiploic artery and omento vessels with an adjustable nylon tie polyamide 6.6 bands (100 $\mathrm{mm}$ x $2.50 \mathrm{~mm}$ ) [yellow arrows].
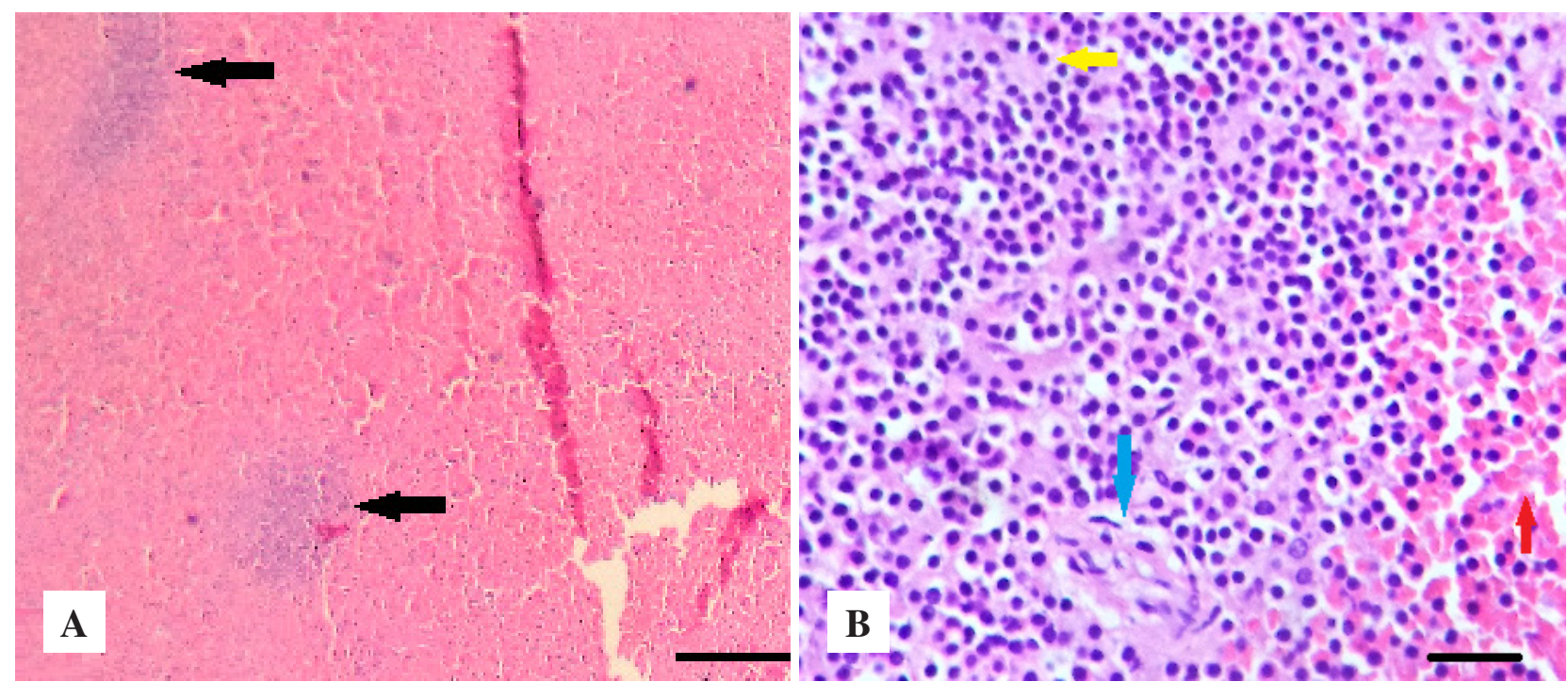

Figure 2. Photomicrography of spleen of a 12-year-old dog diagnosed with hematoma and lymphoid hyperplasia. A- Well defined nodular lesion (black arrows). B- Haemorrhage (red arrows), lymphocytes (yellow arrows) and lymphoplasmatic cell (blue arrow) [HE. 10x e 40x]. [Bar= 100 $\mu$ m]. 
At the recheck examination 10 days after surgery the skin sutures were removed. CBC, serum biochemistry analysis (alanine aminotransferase - ALT, urea and creatinine) was within normal limits. Thoracic radiographs revealed no abnormalities. No abdominal ultrasonographic evidence of tissue reaction to nylon tie bands was observed. Video laparoscopy did not showed any sign of adherence on the local where used the nylon tie bands. One year and three months after the surgery, the owner was contacted by telephone, since he had changed to other city, and he reported that the dog was healthy without any clinical signs. The authors suggested to perform another video laparoscopy, and no alterations where observed.

\section{DISCUSSION}

The present case report describes the clinical and histopathological findings of splenic hematoma and lymphoid hyperplasia, and treatment by splenectomy using an adjustable nylon tie polyamide 6.6 bands in a 2.3-year-old Golden retriever dog. According to the author's knowledge, there are no reports regarding to using nylon tie bands in splenectomy, and hematoma and lymphoid hyperplasia in young dogs, and it reinforces the importance of the present case report.

The adjustable nylon tie bands allowed a secure and faster ligature when compared with traditional nylon surgical suture wires. Nylon tie bands devices are produced with the same material of surgical nylon wires - polyamide 6.6 [28]. The device was considered well tolerated and non-toxic after toxicity analysis [5,9]. It has been used in different surgical procedures in animals and humans patients [7,27]. However, there is no report in the literature concerning using nylon tie bands in splenectomy procedure.

The correct surgical technique and device sterilization are important when using this device [19], as the present report case. Costa Neto et al. [11] evaluated the histopathological tissue reaction produced by the nylon thread and the nylon tie bands implanted in 20 rats. The authors observed that the nylon cable tie induced a rapid course of intense inflammatory reaction, and the inflammatory reaction of the nylon thread was initially exudative and progressed slowly for the repair. On the other hand, it were not observed adherence, macroscopically and histological changes on ovarian pedicles of 18 bitches submitted to ovariohysterectomy by nylon thread and nylon tie bands during sixty days of evaluation [19].
Reports concerning to complications to the use of nylon tie in veterinary surgery were present in the literature $[4,18,20,31]$. On the other hand, these complications were related to surgical technique failure and inadequate aseptic technique; inadequate use of nylon tie bands before assigning it as a hemostatic material. The excessive inflammation and granuloma development observed in surgical cases which used the nylon tie probably is associated with excessive residual devitalised tissue or excessive tissue trauma $[12,14,20,30]$. A new resorbable device tie-rap with the same self-locking mechanism of nylon tie was created by Hoglund et al. [14], but not available in our region.

In the present report, the branch vessels supplying the gastric fundus were preserved during the total splenectomy; the splenic artery and vein, the gastroepiploic artery, the gastric artery and the omento veins were clamped using an adjustable nylon tie polyamide 6.6 band, and no ultrasonographic and video laparoscopy evidence of tissue reaction to nylon tie bands or sign of adherence was observed. Partial splenectomy is recommended for treatment of splenic hematoma and lymphoid hyperplasia in dogs whenever possible; however, the macroscopic findings concerning splenic disorders are not enough to set the distinction between benign and malignant disorders [28]. Thus, the total splenectomy was adopted due to the difficulty to differentiate the benign from the malignant processes during surgery.

A retrospective study, referring to splenic lesions conducted by Bandinelli et al. [2] in splenectomized dogs has shown that $120(69.3 \%)$ out of 173 samples corresponded to neoplastic disorders $(92.5 \%$ of them were malignant and $7.5 \%$, were benign disorders) and $53(30.6 \%)$ corresponded to non-neoplasic disorders. The most common disorders were hemangiossarcoma (44.1\%). The same study also showed the prevalence of splenic disorders in crossbreed dogs (27.9\%), Rottweiler (8.9\%), Cocker spaniels (8.4\%), Poodles $(6.7 \%)$, German shepherds $(6.1 \%)$ and Labrador retrievers (5\%). A study involving 325 dogs submitted to splenectomy to treat splenic mass or nodular disease showed that $32 \%$ of the assessed masses were hemangiosarcoma [27]. On the other hand, hemangiosarcoma was found in $46 \%$ and $65 \%$ of small and large dog splenic neoplasms, respectively [26].

The average age of animals affected by splenic disorders is 8.1 years (range 1 to 15 years) [3], and 10.7 years (range 3 to 20 years) [26]. 
The siderotic nodules have been associated with previous local bleeding $[9,16]$, and characterized through iron and calcium accumulation, degenerated splenic capsule and trabecular connective tissue [16]. The presence of siderotic nodules is proportional to the dog's age due to accumulative damage over the years [16]. On the other hand, the presence of siderotic nodules is associated with splenomegaly [16]. The siderotic nodules were herein associated with age, since there were no clinical signs of splenic hemorrhage. However, the same number of siderotic nodules was found in young and older dogs with splenic hemangiosarcoma and hematoma [9]. The most important clinical sign associated with splenic disorders in the present case was abdominal distension due to hematoma and nodular lymphoid hyperplasia. Others clinical signs, such as anorexia, apathy, regurgitation and weight loss could be secondary to the abdominal distension.

Christensen et al. [8] studied the most common canine splenic disorders diagnosed through cytopathological and histopathological examinations. The most common diagnoses among 51 histopathological diagnoses were growth disorders, vascular disturbances and necrosis (49\%), which was followed by malignant neoplasms (43\%) and inflammatory disorders (8\%). The most common breeds were German shepherd, Boxer and Maltese terrier. Only the histopathological examination was herein performed for final diagnosis since the decision was made to adopt the exploratory laparotomy for excisional (spleen). An adjustable nylon tie polyamide 6.6 band can be used to clamp the spleen vessels, gastroepiploic artery, gastric artery and omento veins during a total splenectomy. The diagnostic imaging approach used in the herein reported case allowed identifying the splenic disorders and their locations, and it enable specifying the preoperative planning of the surgical approach in order to achieve the curative excision of the spleen mass. The splenectomy was the treatment of choice in dogs with hematoma and lymphoid hyperplasia. More studies regarding to long-term analysis of using of an adjustable nylon tie polyamide 6.6 band in splenectomy in dogs must be performed.

\section{MANUFACTURERS}

${ }^{1}$ Zoetis Indústria de Produtos Veterinários Ltda. São Paulo, SP, Brazil.

${ }^{2}$ Cristália Prod. Quím. Farm. Ltda. Itapira, SP, Brazil.

${ }^{3}$ Vetnil Ind. e Com. de Produtos Veterinários Ltda. Louveira, SP, Brazil.

${ }^{4}$ Astrazeneca Brasil. Cotia, SP, Brazil.

${ }^{5}$ Abbott Laboratórios do Brasil. São Paulo, SP, Brazil.

${ }^{5}$ Wurth do Brasil. Cotia, SP, Brazil.

${ }^{6}$ Shalon Suturas. Goiânia, GO, Brazil.

${ }^{7}$ Ethicon, Johnson \& Johnson Brasil Indústria e Comércio Ltda. São Paulo, SP, Brazil.

${ }^{8}$ Aché Laboratórios Farmacêuticos S.A. São Paulo, SP, Brazil. ${ }^{9}$ Ourofino Saúde Animal. Cravinhos, SP, Brazil.

${ }^{10} \mathrm{ABL}$ Antibióticos do Brasil. São Paulo, SP, Brazil.

Declaration of interest. The authors report no conflicts of interest. The authors alone are responsible for the content and writing of the paper.

\section{REFERENCES}

1 Aronsohn M.G., Dubiel B., Roberts B. \& Powers B.E. 2009. Prognosis for acute non traumatic hemoperitoneum in the dog: A retrospective analysis of 60 cases (2003-2006). Journal of American Animal Hospital Association. 45: 72-77.

2 Barros B.J., Sanches A.W.D. \& Pachaly J.R. 2009. Utilização de abraçadeira de náilon 6.6 (poliamida) como método de ligadura de pedículos ovarianos e coto uterino em ovário-histerectomia eletiva em cadelas (Canis familiaris). Arquivo de Ciências Veterinária e Zoologia. 12: 47-60.

3 Bettini G., Mandrioli L., Brunetti B. \& Marcato P.S. 2001. Canine splenic pathology: a retrospective study of 109 surgical samples, with special emphasis on fibrohistiocytic nodules. European Journal of Veterinary Pathology. 7(3): 101-109.

4 Brandão C.V.S., Antunes P.A.U.M., Estanislau C.A., Mamprim M.J., Teixeira L., Padovani C.R., Marinho P.V.T. \& Minto B.W. 2013. Cinta de náilon como cerclagem óssea - estudo experimental em coelhos e ratos. Seminário Ciência Agrária. 34(6): 2903-2914.

5 Bregadioli T., Ferrigno C.R.A., Ferreira M.P., Ferraz V.C.M., Bó I.S.D., Santos J.F., Paes F., Galeazzi V.S., Marinho P.V.T. \& Macedo A.S. 2017. Complicações relacionadas ao uso de abraçadeira de náilon como implante ortopédico. Revista CFMV. 23(72): 67-71.

6 Carrillo J.M., Sopena J.J., Rubio M., Redondo J.I., Serra I. \& Soler C. 2005. Experimental use of polyamide bands in combination with intramedullary pinning for repair of oblique femoral fractures in rabbits. Veterinary Surgery. 34: 387-392. 
7 Chávez-Cartaya R., Jiron-Vargas A., Pinto S., Carretta M., Pino-DeSola G. \& Vegas A.M. 1992. Adjustable nylon ties for abdominal Wall closure. American Journal of Surgery. 163: 609-612.

8 Christensen N., Canfield P., Martin P., Krockenberger M., Spielman D. \& Bosward K. 2009. Cytopathological and histopathological diagnosis of canine splenic disorders. Australian Veterinary Journal. 87(5): 175-181.

9 Cole P.A. 2012. Association of canine splenic hemangiosarcomas and hematomas with nodular lymphoid hyperplasia or siderotic nodules. Journal of Veterinary Diagnostic Investigation. 24: 759.

10 Costa Neto J.M., Teixeira E.M., Ferreira Filho E.M., Toríbio J.M.M.L., Almeida Filho C.H.R. \& Moraes V.J. 2009. Braçadeiras de náilon para hemostasia preventiva da ováriossalpingohisterectomia em gatas. Revista Brasileira de Saúde e Produção Animal. 10(3): 615-624.

11 Costa Neto J.M., Lima A.E.S., Ória, A.P., Ferreira Filho E.M. \& Teixeira D.M. 2014. Análise histopatológica das reações teciduais produzidas pelo implante de fio e de braçadeira de náilon. Enciclopédia biosfera. 10(18): 291-299.

12 Cunha M.G.M.C.M., Pippi N.L., Santos Junior E.B., Gomes K., Fontes E.B., Cunha J.P.M.C.M., Serafini G.M.C., Klock K.A. \& Monique T. 2010. Cerclagem com abraçadeira de náilon ou de fio de aço no reparo de fraturas experimentais de sínfise mandibular em gatos. Acta Scientiae Veterinariae. 38(4): 363-369.

13 Fife W.D., Samii V.F., Drost W.T., Mattoon J.S. \& Hoshaw-Woodard S. 2004. Comparison between malignant and nonmalignant splenic masses in dogs using contrast-enhanced computed tomography. Veterinary Radiology and Ultrasound. 45(4): 289-297.

14 Finger M.A., Dornbusch P.T., Bonfa A., Dornbusch L.P.T.C., Deconto I. \& Barros Filho I.R. 2011. Comparação de duas técnicas de orquiectomia em equinos, empregadas no ensino da técnica cirúrgica veterinária. Archive of Veterinary Science. 16(3): 53-59.

15 Hoglund O.V., Hagman R., Olsson K., Mindermark J., Borg N. \& Lagerstedt A.S. 2011. A new resorbable device for ligation of blood vessels - a pilot study. Acta Veterinaria Scandinavica. 53: 47.

16 Huang-Qing O., Jiong Z.G., Fei Y.Z., Sheng C.S. \& Hui Z.Y. 2013. Splenic siderotic nodules in patients with liver cirrhosis. Experimental and Therapeutic Medicine. 6: 445-450.

17 Lima A.F.M., Luna S.P.L, Rodrigues M.M.P. \& Quitzan J.G. 2010. Avaliação histológica e videolaparoscópica de ligaduras dos pedículos ovarianos realizados com mononáilon agulhado ou abraçadeiras autoestáticas de náilon em cadelas submetidas ováriosalpingohisterectomia pela técnica do gancho. Ars Veterinaria. 26(2): 66-70.

18 Macedo A.S., Dal-Bo I.S., Quadros A.M., Brambatti G., Reis K.D.H.L., Brun M.V., Alievi M.M. \& Beck C.A.C. 2012. Complications associated with ovariohysterectomy using nylon tie-rap as a hemostatic method. Acta Scientiae Veterinariae. 40: 1086.

19 Marujo R.B., Luna S.P.L, Lima A.F.M. \& Santos I.F.C. 2013. Abraçadeira autoestática de náilon na cirurgia veterinária: revisão de literatura. Nosso Clínico. 96: 50-54.

20 Mesquita L.R., Rahal S.C., Matsubara L.M., Mamprim M.J., Foschini C.R., Faria L.G. \& Kano W.T. 2015. Bilateral hydronephrosis and hydroureter after ovariohysterectomy using nylon cable tie: a case report. Veterinarni Medicina. 60(1): 52-56

21 Murphy S.T., Newell S.M. \& Burrows C.F. 1998. What is your diagnosis? Journal of the American Veterinary Medical Association. 212: 193-196.

22 Rabelo R.E., Silva L.A.F., Sant'Ana J.F., Silva M.A.M., Moura M.I., Franco L.G. \& Oliveira C.R. 2008. Uso de abraçadeira de poliamida para ovariectomia em éguas em posição quadrupedal. Acta Scientiae Veterinariae. 36(2): 19-125.

23 Santos I.F.C., Canda R., Augusto L., Bambo O. Mataveia G. \& Oliveira K.C. 2012. Eficácia da abraçadeira e do fio de náilon na deferentectomia e laqueação dos ductos deferentes em cães adultos (Estudo comparativo). ARS Veterinária. 28(2): 75-84.

24 Santos I.F.C., Bene M. \& Gaspar B. 2014. Eficácia dos métodos de antissepsia e esterilização da abraçadeira autoestática de náilon. Revista Científica Medicina Veterinária.12(22): 132-135.

25 Sherwood J.M., Haynes A.M., Klocke E., Higginbotham M.L, Thomson E.M., Weng H. \& Millard H.A.T. 2016. Occurrence and Clinicopathologic Features of Splenic Neoplasia Based on Body Weight: 325 Dogs (2003-2013). Journal of American Animal Hospital Association. 52(4): 220-226.

26 Silva L.A.F., França R.O., Vieira D., Garcia A.M., Moura M.I., Silva M.A.M., Silva M.A.M., Silva E.B., Trindade B.R. \& Franco L.G. 2007. Emprego da abraçadeira de náilon, do categute e do emasculador na hemostasia preventiva de ovariectomia em éguas. Ciência Animal Brasileira. 8(1): 135-146. 
I.F.C. Santos, M.D. Del Poente, G.C. Brombini, et al. 2017. Hemostasis Technique Using an Adjustable Nylon Tie in Dog with Splenic Hematoma and Lymphoid Hyperplasia.

27 Silva L.A.F., Soares A.C., Borges L.K., Ferreira J.L. \& Cardoso L.L. 2009. Orquiectomia em bovinos empregando abraçadeira de náilon na hemostasia preventiva: Efeito da estação do ano, método de contenção cirúrgica. Ciência Animal Brasileira. 10(1): 261-270.

28 Sorbello A.A., Giudugli Neto J. \& Andretto R. 1999. Nova alternativa para ligadura em cirurgias vídeo-endoscópicas ou convencionais, com emprego de fitas de náilon em estudo experimental. Revista Brasileira de Coloproctologia. 19(1): 24-26.

29Spangler W.L. \& Culbertson M.R. 1992. Prevalence, type, and importance of splenic diseases in dogs: 1,480 cases (1985-1989). Journal of American Veterinary Medicine Association. 200(6): 829-834.

30 Werner R.E., Straughan A.J. \& Vezin D. 1992. Nylon cable band reactions in ovariohysterectomized bitches. Journal of the American Veterinary Medical Association. 200: 64-66. 